\title{
10. BASAL DOLOMITIC SEDIMENTS, TYRRHENIAN SEA, OCEAN DRILLING PROGRAM LEG 1071
}

\author{
J. A. McKenzie, ${ }^{2}$ A. Isern, ${ }^{3}$ A. M. Karpoff, ${ }^{4}$ and P. K. Swart ${ }^{5}$
}

\begin{abstract}
Basal dolomitic sediments were recovered at three drill sites in the Tyrrhenian Sea during Ocean Drilling Program (ODP) Leg 107 (Sites 650, 651, and 655). These sediments overlie the basaltic basement complex and are enriched in iron, and in some instances, also in manganese. The manganese enrichments, together with a very slight enrichment in trace transition elements, strongly suggest that the basal sediments have an affinity to deep-sea metalliferous deposits of hydrothermal origin. At Sites 651 and 655 , the dolostones contain variable amounts of authigenic palygorskite, a Mgrich clay mineral. At Site 651 , the basal sediments are $40 \mathrm{~m}$ thick and contain nonstoichiometric dolomite, sometimes $\mathrm{Ca}$ rich, but primarily $\mathrm{Mg}$ rich. The occurrence of $\mathrm{Mg}$-rich dolomite with excess $\mathrm{Mg}$ up to $4 \%$ is unusual for the deepsea environment; it may be associated with a hydrothermally driven flux of altered sea water through the directly underlying basement complex, which comprises basalt, dolerite, and serpentinized peridotite. Low-temperature alteration of the basement complex could produce solutions enriched in $\mathrm{Mg}$. Oxygen-isotope equilibrium temperatures indicate that all of the studied dolomites formed under low-temperature conditions (i.e., $<70^{\circ} \mathrm{C}$ ). The carbon-isotope compositions, together with the strong isotopic covariance, suggest that the $\mathrm{Mg}$-rich dolomite precipitated more rapidly than the Carich dolomite.

We suggest that the low-temperature, hydrothermal convection of $\mathrm{Mg}$-rich solutions through the basal sediments in this back-arc basin environment (1) overcame kinetic problems related to the formation of massive dolostones, and (2) provided a mass-transport mechanism for dolomitization.
\end{abstract}

\section{INTRODUCTION}

The Tyrrhenian Sea in the western Mediterranean is a small oceanic back-arc basin that opened behind a volcanic arc and above a subduction zone. The areas surrounding this small triangular sea are quite well known for widespread active volcanism and frequent earthquake tremors, attesting to the continuing tectonic activity at the subduction plate boundary. The thermal regime in the central Tyrrhenian Basin is characterized by relatively high heat flow, with maximum values greater than 200 $\mathrm{mW} / \mathrm{m}^{2}$ in the Vavilov and Marsili Basins. Regionally, in these two sub-basins, very low and extremely high heat flow anomalies have been observed. These have been attributed to hydrothermal circulation (e.g., Rehault et al., 1987).

A major objective of ODP Leg 107 was to investigate the evolution of the back-arc basin, in part by determining the age and geochemistry of the basaltic basement. In conjunction with this objective, the possible existence of metalliferous sediments overlying the basement was to be probed. To accomplish these goals, three sites in the two easterly sub-basins of the Tyrrhenian Sea were drilled to igneous basement, in water depths between 3330 and $3590 \mathrm{~m}$ : (1) the western rim of the Vavilov Basin near the crest of a north-south trending ridge (Site 655); (2) the axis of the Vavilov Basin on the eastern flank of a north-south trending basement swell (Sites 651); and (3) the western rim of the Marsili Basin (Site 650) (Shipboard Scientific Party, 1987a, b, d; see also Fig. 1).

\footnotetext{
${ }^{1}$ Kastens, K. A., Mascle, J., et al., 1990. Proc. ODP, Sci. Results, 107: College Station, TX (Ocean Drilling Program).

2 Geological Institute, ETH-Zentrum, 8092 Zürich, Switzerland.

${ }^{3}$ Graduate School of Oceanography, University of Rhode Island, Narragansett, RI 02882 .

4 Centre de Sédimentologie et Géochimie de la Surface-CNRS, 1, rue Blessig, 67084 Strasbourg, France.

${ }^{5}$ Marine Geology and Geophysics, RSMAS, University of Miami, 4600 Rickenbacker Causeway, Miami, FL 33149.
}

The oldest biostratigraphically datable sediments above basement along this three-site transect become younger (latest early Pliocene to latest late Pliocene) from northwest to southeast, suggesting that the locus of oceanic accretion in the back-arc basin has migrated, through time, from northwest to southeast towards the subduction zone. The recovered basement rocks varied among the sites. At Site $650,32 \mathrm{~m}$ of vesicular basalt were cored, compared with $110 \mathrm{~m}$ of basalt flows at Site 655 ; deeper coring at Site 651 revealed an unexpectedly complex basement assemblage containing highly serpentinized peridotites overlain by $30 \mathrm{~m}$ of basalt and basaltic breccia, followed by $28 \mathrm{~m}$ of dolerite, metasediments and metadolerite, capped by 76 m of basalt flows (Shipboard Scientific Party, 1987a, b, d).

At all three sites the basement rocks are directly overlain by dolomitic sediments. The presence of dolomitized pelagic sediments overlying deep-sea basalt is not a new discovery, having been recognized with the early drilling results from the experimental Mohole site in the Pacific Ocean (Riedel et al., 1961; Murata and Erd, 1964). Stable isotope data suggested that the well-indurated dolomite recovered above the Mohole basalt was formed in isotopic equilibrium with normal marine water at an ambient bottom water temperature of approximately $5^{\circ} \mathrm{C}$ (Degens and Epstein, 1964). Other occurrences of authigenic, deepsea dolomite apparently have a hydrothermal origin (Bonatti, 1966).

Subsequent drilling during the Deep Sea Drilling Project (DSDP) produced more examples of dolomitization of sediments in close proximity to the oceanic basement (see Garrison, 1981 , for a partial review of these occurrences). One such example particularly relevant to ODP Leg 107 was cored at DSDP Site 373 in the Vavilov sub-basin of the Tyrrhenian, where moderately well-lithified, ferruginous, calcium-rich dolomite was recovered stratigraphically sandwiched between basaltic breccia and soft nannofossil marl (Bernoulli et al., 1978). Isotope data likewise indicated an origin in cold marine waters, while petrographic observations suggested that the dolomite had replaced or infilled molds of probable foraminifers. 

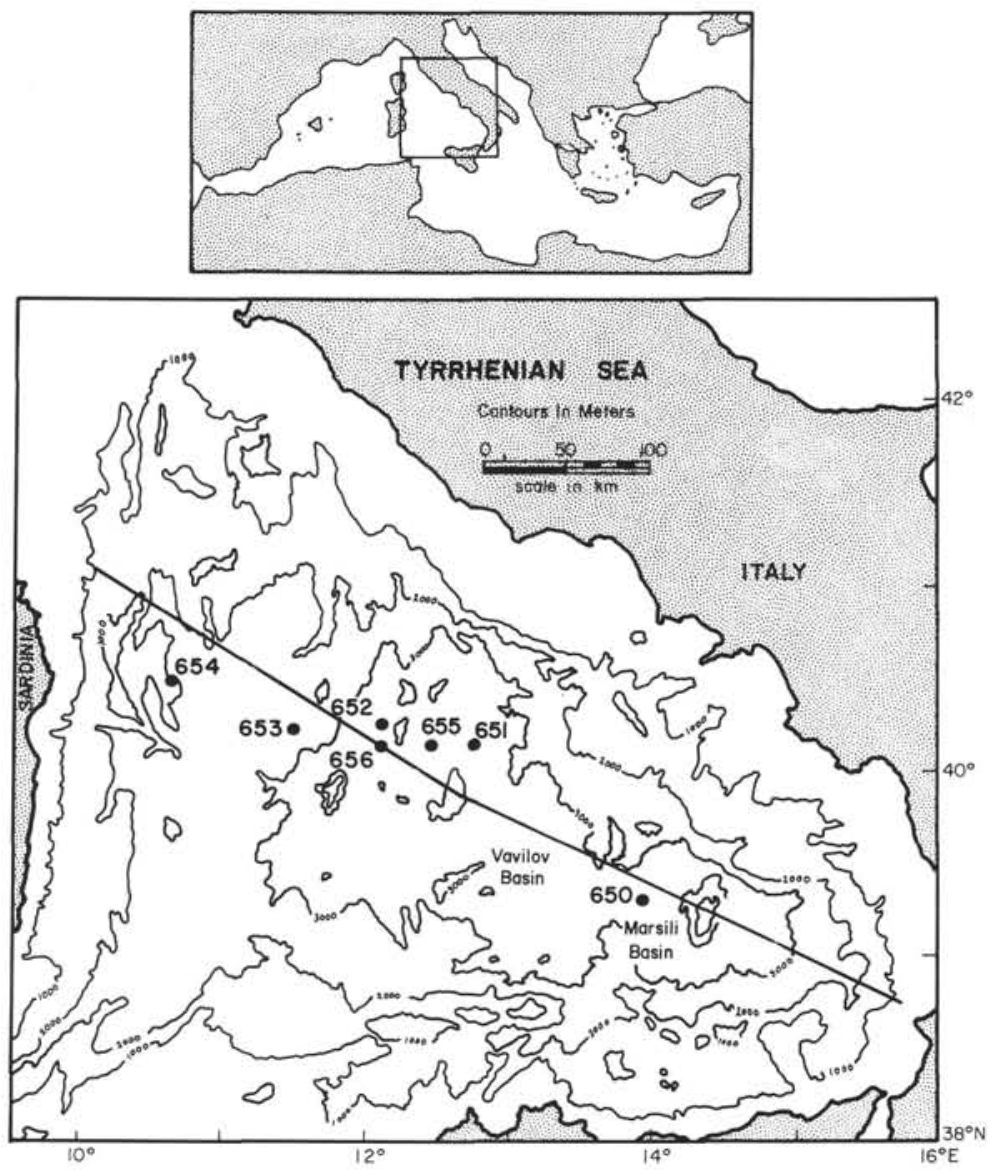

Figure 1. Map of the Tyrrhenian Sea; basal dolomitic sediments overlying basalt were recovered at Sites 650,651 , and 655 . The general bathymetry is simplified from the international bathymetric chart of the Mediterranean Intergovernmental Oceanographic Commission (UNESCO, 1981).

Although not particularly unforeseeable, the recovery of basal dolomitic sediments during ODP Leg 107 nevertheless stimulated interest among the shipboard scientific party because of the sediments' extensive thickness and brightly colored, metalliferous appearance. This study evaluates and compares the geochemical characteristics of the dolostones found at the three Tyrrhenian Sea drilling sites in order to determine if the dolostones are truly metalliferous, and to reconstruct the environment of their origin.

\section{DESCRIPTION OF DOLOSTONES}

The dolostones or dolomitic sediments stratigraphically overlying igneous basement at the three sites differ in their appearance, composition and thickness, as observed during routine core description (Shipboard Scientific Party, 1987a, b, d). At the more westerly Site 655 in the Vavilov Basin the basal dolomite must be relatively thin, as only approximately $25 \mathrm{~cm}$ of dark brown dolostone were recovered in the core catcher of Core 107-655A-9X (79.9 meters below sea floor, or mbsf). The dolostone was in drilling contact with an aphanitic basalt showing chilled glass margins. The $6.4 \mathrm{~m}$ of sediment directly overlying the contact consists of foraminifer-rich nannofossil ooze, which shows a progressive downhole change in color from yellow to brown, and is abundantly speckled with black material, presumably metalliferous. The downward increase in the intensity of the coloration suggests that a dolomitization or diagenetic front may have moved upward from the sediment/base- ment contact. A single dolostone sample (Sample 107-655A-9X, CC [23-24 cm], here called Sample BD4) from directly above the sediment/basalt contact $(79.9 \mathrm{mbsf})$ was selected for this study.

At the relatively nearby Site 651 , the basal dolomitic interval is considerably more extensive, being approximately $39.8 \mathrm{~m}$ thick. Core recovery within the dolomitic interval was rather good $($ average $=67 \%$ ), which allows for a relatively complete visual inspection of the sequence. On this basis the interval can be divided into two levels: (1) an upper level represented by Core 107-651A-38R (347.8-357.5 mbsf); (2) a lower level found in Cores 107-651A-39R to -41R (357.5-386.5 mbsf), which is followed by the basement complex beginning at the top of Core 107-651A-42R (386.5 mbsf). Below Section 107-651A-38R-2 (349.3 mbsf), no microfossils are present in the sediment, probably as a consequence of diagenetic alteration. The upper level contains dolomitic claystone and dolostone of more subdued color, in contrast to the brightly colored dolostone in the lower level. The lower sediments vary intergradationally between hues of orange, greenish grays, yellowish reds and browns, to nearly black. The dolostone is speckled with black segregations (probably manganese oxide) present as burrow fills and in disseminated dendritic patterns.

Within the underlying basalt in Core 107-651A-50R (464.5 mbsf) a 30-cm-thick interval of dolomitic sediment, similar to that above the basalt, was recovered. Furthermore, within the basaltic and doleritic units of the basement complex, dolomite 
cement and dolomitized sediment frequently infill cavities. From a visual inspection of the various dolomite occurrences at Site 651 , the dolomitization process appears to be more complex than at nearby Site 655 and may be comprised of multiple dolomitization events. Twenty-nine carbonate samples from throughout the basal dolomitic sequence and the underlying basement complex were selected for this study, including one sample of the overlying undolomitized calcareous nannofossil ooze.

At the easternmost Marsili Basin site (Site 650), approximately $2.1 \mathrm{~m}$ of the basal dolostone or dolomitic mudstone unit were recovered in Core 107-650A-66X (599.8-604.8 mbsf), in drilling contact with the underlying basalt. The reddish brown dolostones are dominated by small, euhedral dolomite crystals. Microfossils are practically nonexistent in these sediments; no black metalliferous material was noted. A sample of greenish gray dolostone from directly above the sediment/basalt contact (Sample 107-650A-66X-2, 53-54 cm = Sample BD2) and one of the overlying reddish brown dolostone (Sample 107-650A-66X-2, $47-48 \mathrm{~cm}=$ Sample BD1) were selected for this study. The sediments in the overlying core (107-650A-65X, 594.1-599.8 mbsf) consist of greenish gray nannofossil ooze with a brownish overprint. A potentially metalliferous horizon occurs at the base of this core.

\section{ANALYTICAL PROCEDURES}

In order to evaluate and compare the geochemical characteristics of the basal dolostone, we undertook an investigation of the carbonate and clay mineralogy, percent carbonate, major and trace elements, and stable isotope composition of the selected samples. Samples were selected onboard the JOIDES Resolution on the basis of lithology and color. Prior to performing any analyses, we ground the samples and disaggregated them in several aliquots of deionized water to remove any residual salts, then dried them in an oven at $40^{\circ} \mathrm{C}$. The investigated samples are listed in Table 1 according to a laboratory number (e.g., Sample BD1, BD2, etc).

The percent carbonate in the bulk samples was obtained using a vacuum-gasometric technique with an accuracy of $\pm 0.25 \%$ (Jones and Kaiteris, 1983). The percent carbonate values range between $28 \%$ and $86 \%$ (Table 1). Routine X-ray diffraction analyses were made on the powdered samples, using a General Electric XRD-5 diffractometer to determine the carbonate mineralogy. All samples were run between $23^{\circ}$ and $65^{\circ} 2 \theta$ at $35 \mathrm{kV} / 20 \mathrm{~mA}$, using $\mathrm{CuK} \alpha$ radiation, Ni filter and a scan speed of $2^{\circ} 2 \theta / \mathrm{min}$. The carbonate component in all but two samples was $100 \%$ dolomite. The carbonate mineralogy of Sample BD5 (nannofossil chalk from above the dolostone interval at Site 651) was $100 \%$ calcite, while the stratigraphically lower Sample BD6 contained a 44:56 calcite:dolomite mixture, based on relative peak heights. The bulk of the samples can be classified as dolomitic claystone or dolostone on the basis of their carbonate content.

In order to estimate the mole fraction of $\mathrm{MgCO}_{3}$ in the dolomite, the position of the major dolomite $\{10.4\}$ peak relative to the detrital quartz $\{10.1\}$ peak was measured. In the case of Samples BD28, BD30, and BD32, which contained no quartz, the $\{11.1\}$ peak of an internal silicon standard from the National Bureau of Standards (NBS) was used. The measured difference in d-spacing was used to obtain the $\mathrm{mol} \% \mathrm{Mg}$ in the dolomite from the standardized curves developed by Goldsmith et al. (1955). The results are given in Table 1. As the accuracy of this method is at best $\pm 2 \mathrm{~mol} \%$, the Site 651 dolomites were analyzed further using standard atomic absorption (AA) methods for chemical determination of the $\mathrm{Ca}, \mathrm{Mg}, \mathrm{Fe}$, and $\mathrm{Mn}$ composition of the dolomite fraction. One gram of sample was reacted for 10 minutes with $10 \mathrm{ml}$ of $1 \mathrm{~N} \mathrm{HCl}$. The solutions were filtered and split; one half was used to analyze for $\mathrm{Fe}$ and the other half was diluted to measure for $\mathrm{Mn}$, $\mathrm{Ca}$, and $\mathrm{Mg}$. The data are presented in Table 2 .

The AA analysis was made to determine if the presence of $\mathrm{Fe}$ or $\mathrm{Mn}$ in the dolomite was sufficient to cause the $\{10.4\}$ peak shift. If it is assumed that most of the $\mathrm{Mg}$ and $\mathrm{Ca}$ come from the carbonate fraction of the samples, the $\mathrm{Mg}$ composition obtained from the $\mathrm{AA}$ analysis can be recalculated as $\mathrm{mol} \% \mathrm{Mg}$ of the dolomite. These calculated values of $\mathrm{mol} \% \mathrm{Mg}$ are given in Table 1 and suggest that many of the basal dolomites are indeed enriched in $\mathrm{Mg}$, as indicated by the X-ray diffraction analysis.
Table 1. Percent carbonate and $\mathrm{mol} \% \mathrm{Mg}$ in dolomites from Sites 650, 651 , and 655 .

\begin{tabular}{|c|c|c|c|c|c|}
\hline $\begin{array}{l}\text { Sample } \\
\text { code }\end{array}$ & $\begin{array}{l}\text { Core, section, } \\
\text { interval }(\mathrm{cm})\end{array}$ & $\begin{array}{l}\text { Depth } \\
\text { (mbsf) }\end{array}$ & $\begin{array}{c}\text { Carbonate } \\
(\%)\end{array}$ & $\underset{(\mathrm{mol} \%)^{\mathrm{a}}}{\mathrm{Mg}}$ & $\underset{(\mathrm{mol} \%)^{\mathrm{b}}}{\mathrm{Mg}}$ \\
\hline \multicolumn{6}{|l|}{$107-650 \mathrm{~A}-$} \\
\hline BD1 & $66 \times-2,47-48$ & 601.8 & 86.1 & 43 & \\
\hline BD2 & $66 \mathrm{X}-2,53-54$ & 601.9 & 68.1 & 43 & \\
\hline \multicolumn{6}{|l|}{$107-655 \mathrm{~A}-$} \\
\hline BD4 & $9 \mathrm{X}, \mathrm{CC},(23-24)$ & 79.9 & 70.4 & 46 & \\
\hline \multicolumn{6}{|l|}{ 107-651A- } \\
\hline BD5 & $37 \mathrm{R}-1,70-71$ & 347.9 & 50.8 & & \\
\hline BD6 & $38 \mathrm{R}-1,134-135$ & 349.1 & 31.5 & 43 & \\
\hline BD7 & $38 \mathrm{R}-2,90-91$ & 350.2 & 37.9 & 47 & 47 \\
\hline BD8 & $38 R-4,31-32$ & 352.6 & 41.4 & 47 & 49 \\
\hline BD9 & $39 \mathrm{R}-2,20-21$ & 359.2 & 42.2 & 43 & 48 \\
\hline BD10 & $39 R-2,102-103$ & 360.0 & 46.2 & 51 & 53 \\
\hline BD11 & $39 R-4,138-139$ & 363.4 & 51.9 & 53 & 53 \\
\hline BD12 & $40 \mathrm{R}-1,98-99$ & 368.2 & 43.8 & 50 & 54 \\
\hline BD13 & $40 \mathrm{R}-3,19-20$ & 370.4 & 52.2 & 51 & 52 \\
\hline BD14 & $40 \mathrm{R}-3,114-115$ & 371.3 & 55.3 & 52 & 51 \\
\hline BD15 & $41 \mathrm{R}-1,60-61$ & 377.4 & 40.2 & 54 & 54 \\
\hline BD16 & $41 \mathrm{R}-2,60-61$ & 378.9 & 38.2 & 49 & 53 \\
\hline BD17 & $41 \mathrm{R}-3,49$ & 380.3 & 45.6 & 50 & 51 \\
\hline BD18 & $41 \mathrm{R}-3,50$ & 380.3 & 47.4 & 51 & 49 \\
\hline BD19 & $41 \mathrm{R}-3,51$ & 380.3 & 43.1 & 51 & \\
\hline BD20 & $41 R-4,80-82$ & 382.1 & 32.2 & 51 & 54 \\
\hline BD21 & $41 \mathrm{R}-5,58-60$ & 383.4 & 28.2 & 51 & 54 \\
\hline BD22 & $41 \mathrm{R}-5,79-81$ & 383.6 & 43.4 & 53 & 53 \\
\hline BD23 & $41 \mathrm{R}, \mathrm{CC}(6-7)$ & 384.4 & 52.8 & 52 & 53 \\
\hline BD24 & $41 \mathrm{R}, \mathrm{CC}(21-22)$ & 384.5 & 56.2 & 54 & 48 \\
\hline BD25 & $42 \mathrm{R}-1,7-10$ & 386.6 & 51.0 & 47 & 47 \\
\hline BD26 & $50 \mathrm{R}-1,41-44$ & 464.4 & 39.4 & 50 & 53 \\
\hline BD27 & $50 \mathrm{R}-1,61-64$ & 464.6 & 39.4 & 54 & \\
\hline BD28 & $42 \mathrm{R}-1,101-104$ & 387.5 & 84.2 & 48 & 50 \\
\hline BD29 & $43 R-2,70-73$ & 398.4 & 53.3 & 47 & 48 \\
\hline BD30 & $52 \mathrm{R}-1,110-112$ & 484.4 & 70.2 & 48 & 49 \\
\hline BD32 & $54 \mathrm{R}-2,0-2$ & 504.0 & 72.9 & 42 & 45 \\
\hline BD33 & $55 \mathrm{R}-2,124-125$ & 514.9 & 53.7 & 46 & 44 \\
\hline BD35 & $42 \mathrm{R}-1,27-30$ & 386.8 & 40.5 & 46 & \\
\hline
\end{tabular}

${ }^{a}$ From X-ray diffraction analysis.

${ }^{b}$ From atomic absorption spectrometric analysis.

Table 2. Major cation composition $(w t \%)$ of Site 651 dolomites.

\begin{tabular}{|c|c|c|c|c|}
\hline Sample & $\mathrm{CaO}$ & $\mathrm{MgO}$ & $\mathrm{Fe}_{2} \mathrm{O}_{3}$ & $\mathrm{Mn}_{3} \mathrm{O}_{4}$ \\
\hline BD6 & 35.05 & 11.42 & & 0.269 \\
\hline BD7 & 21.87 & 14.20 & & 0.252 \\
\hline BD8 & 20.89 & 14.60 & 0.118 & 0.217 \\
\hline BD9 & 18.92 & 12.51 & 0.104 & 0.140 \\
\hline BD10 & 13.46 & 10.78 & 0.235 & 0.124 \\
\hline BD11 & 14.27 & 11.65 & 0.134 & 0.145 \\
\hline BD12 & 15.84 & 13.39 & 0.151 & 0.048 \\
\hline BD13 & 16.62 & 12.85 & 0.140 & 0.055 \\
\hline BD14 & 20.08 & 14.79 & 0.0 & 0.019 \\
\hline BD15 & 15. & 13.02 & 0.0 & 0.014 \\
\hline BD16 & 18.48 & 15.13 & 0.1 & 0.115 \\
\hline BD17 & 21.72 & 16.22 & 0.0 & 0.164 \\
\hline BD18 & 28.46 & 19.50 & 0.1 & 0.211 \\
\hline BD20 & 16.03 & 13.62 & 0.2 & 0.166 \\
\hline BD21 & 13.20 & 11.03 & 1.030 & 0.151 \\
\hline BD22 & 18.23 & 14.62 & 0.172 & 0.098 \\
\hline BD23 & 15.03 & 11.96 & 0.155 & 0.038 \\
\hline BD24 & 26.00 & 16.98 & 0.050 & 0.084 \\
\hline BD25 & 21.3 & 13.74 & 0.0 & 0.012 \\
\hline BD26 & 15.88 & 13.08 & 0.368 & 0.072 \\
\hline BD28 & 9.47 & 6.79 & 0.032 & 0.054 \\
\hline BD29 & 8.73 & 5.85 & 0.055 & 0.006 \\
\hline BD30 & 9.98 & 7.01 & 0.054 & 0.009 \\
\hline BD32 & 14.53 & 8.66 & 0.045 & 0.052 \\
\hline BD33 & 36.40 & 20.61 & 0.080 & 0.170 \\
\hline
\end{tabular}


For 12 samples from Sites 650,651 , and 655 , the clay fraction $(<2$ $\mu \mathrm{m})$ was separated and a X-ray diffraction analysis was run on four types of oriented aggregates: (1) untreated, (2) ethylene-glycol treated, (3) hydrazine treated, and (4) heated. The following diffractometer conditions were used: $\mathrm{CuK} \alpha$ radiation, Ni filter, $40 \mathrm{kV} / 18 \mathrm{~mA}, 0.2-1^{\circ}$ slits, and $1^{\circ} 2 \theta / \mathrm{min}$ scan speed. The untreated clay fraction was also studied under a Phillips EM300 transmission electron microscope (TEM). The results are discussed below.

As the basal dolostones appeared to be metalliferous, major and trace elemental analyses were run on the bulk samples to evaluate this interpretation. Prior to elemental analysis, the samples were melted in a mixture of lithium tetraborate and introduced into a glycolated solvent. Major element analyses were performed following the method described by Besnus and Rouault (1973) using arc spectrometry and an ARL quantimeter. Trace elements were determined using an inductively-coupled plasma technique (ICP-35000C-ARL) (Samuel et al., 1985). Na and $\mathrm{K}$ contents were determined by emission spectrometry. Major element data (in \% oxides) and minor element data (in ppm) are given in Table 3 and 4 , respectively. The relative precision is $\pm 2 \%$ for major elements and $\pm 10 \%$ for trace elements. It is interesting to note that the unaltered pelagic sediment (Sample BD5) from Site 651 contains 8 to 10 times more $\mathrm{Sr}$ than the dolomitized sediments, a possible reflection of the degree of alteration.

Stable isotope analyses were performed on the carbonates, as well as on selected interstitial pore waters, which were routinely squeezed from sediments onboard the JOIDES Resolution. Oxygen and carbon isotope measurements of the carbonates were run on $\mathrm{CO}_{2}$ gas produced using a modified method of dissolution in phosphoric acid at $50^{\circ} \mathrm{C}$ (McCrea, 1950; Wachter and Hayes, 1985). Analyses of 100\%-dolomite samples were corrected for fractionation (a result of phosphoric acid dissolution) using an alpha value of 1.0102 for $50^{\circ} \mathrm{C}$ (Sharma and Clayton, 1965; Swart, unpubl. data). The oxygen isotopic composition of the waters was determined on $\mathrm{CO}_{2}$ equilibrated with $1 \mathrm{~cm}^{3}$ of sample following the technique of Epstein and Mayeda (1953). The water samples were analyzed in duplicate, as there was some concern about isotopic fractionation resulting from post-cruise storage in either plastic or glass containers. All isotopic analyses were made using a Finnigan-Mat 251 mass spectrometer and are corrected following the procedure of Craig (1957) modified for a triple collector. Reproducibility determined by replicate analyses is better than $\pm 0.1 \%$. Isotopic data for carbonates are quoted relative to the PDB international standard, while water data are reported relative to SMOW (Tables 5 and 6 ).

\section{DISCUSSION OF RESULTS}

\section{Ca-rich Vs. Mg-rich Dolomites}

In general, diagenetic dolomites are found to be either stoichiometric (i.e., the $\mathrm{Ca}: \mathrm{Mg}$ mole ratio is $50: 50$ ) or enriched in calcium ions over magnesium ions. Therefore, it was quite unusual to note during routine X-ray diffraction analysis that 17 samples from Site 651 contain dolomite apparently enriched in $\mathrm{Mg}$. Further chemical analyses appear to confirm that these dolomites are indeed $\mathrm{Mg}$ rich, containing an average of $4 \mathrm{~mol} \%$ excess $\mathrm{MgCO}_{3}$. In Figure 2, the average mol\% $\mathrm{Mg}$ obtained from the two analytical methods (Table 1) is plotted against subbottom depth for Site 651. The distribution of Mg-rich dolomite is apparently stratigraphically controlled, as it is found in two discrete intervals between 360 and 384.5 mbsf and at 464.5 mbsf. These two intervals represent (1) the brightly colored sediments directly overlying the upper basalt unit, and (2) equivalent sediments within the upper part of the underlying dolerite unit. The less colorful dolostone found between $360 \mathrm{mbsf}$ and the partially dolomitized pelagic sediments at 349 mbsf contains Ca-rich dolomite. The carbonate cementing and infilling cavities within the basalt, basaltic breccia, and dolerite units is also Ca-rich dolomite.

A cross-plot of oxygen isotope vs. carbon isotope ratios of the analyzed samples from Sites 650,651 , and 655 , as well as from DSDP Site 373 , shows that the dolomite defines two covariant trends (Fig. 3). The sedimentary Ca-rich dolomite from Sites 651 and 655 appears to define one covariant trend, whereby the $\delta^{13} \mathrm{C}$ values are relatively more depleted, ranging between $-0.29 \%$ and $1.87 \%$. The $\delta^{18} \mathrm{O}$ values vary from $-0.55 \% 0$ to $5.32 \% 0$. The equation of the regression line fitted to these points is:

$$
\mathrm{Y}=0.146+0.321 \mathrm{X}(\mathrm{R}=0.96) \text {. }
$$

The Site 651 basaltic Ca-rich dolomite and sedimentary $\mathrm{Mg}$ rich dolomite, together with the Ca-rich dolomite of Site 650 , define a second covariant trend, which can be divided into two overlapping fields based on the cation ratios in the dolomite.

Table 3. Chemical composition of bulk samples of dolostones from Sites 650, 651, and 655: major elements (wt $\%$ ).

\begin{tabular}{|c|c|c|c|c|c|c|c|c|c|c|c|c|}
\hline Sample & $\mathrm{SiO}_{2}$ & $\mathrm{Al}_{2} \mathrm{O}_{3}$ & $\mathrm{MgO}$ & $\mathrm{CaO}$ & $\mathrm{Fe}_{2} \mathrm{O}_{3}$ & $\mathrm{Mn}_{3} \mathrm{O}_{4}$ & $\mathrm{TiO}_{2}$ & $\mathrm{P}_{2} \mathrm{O}_{5}$ & $\mathrm{Na}_{2} \mathrm{O}$ & $\mathrm{K}_{2} \mathrm{O}$ & L.O.I.* & Total \\
\hline BD1 & 22.9 & 6.8 & 10.8 & 20.8 & 5.0 & 1.730 & 0.33 & 0.15 & 0.47 & 1.28 & 30.26 & 100.52 \\
\hline $\mathrm{BD} 2$ & 23.6 & 6.5 & 10.6 & 20.5 & 4.8 & 1.730 & 0.33 & 0.15 & 0.42 & 1.33 & 30.03 & 99.99 \\
\hline BD4 & 11.7 & 4.3 & 15.4 & 26.4 & 2.1 & 0.305 & 0.25 & 0.14 & 0.24 & 0.57 & 38.01 & 99.41 \\
\hline BD5 & 25.0 & 8.5 & 2.6 & 29.1 & 3.3 & 0.252 & 0.38 & 0.16 & 0.44 & 1.71 & 27.41 & 98.85 \\
\hline BD6 & 37.5 & 11.6 & 6.2 & 14.8 & 4.7 & 0.190 & 0.52 & 0.17 & 0.64 & 2.56 & 21.35 & 100.23 \\
\hline BD7 & 31.9 & 10.0 & 9.9 & 15.0 & 3.8 & 0.239 & 0.48 & 0.14 & 0.55 & 2.18 & 24.91 & 99.10 \\
\hline BD8 & 31.1 & 10.0 & 9.9 & 14.3 & 5.2 & 0.227 & 0.45 & 0.15 & 0.53 & 2.11 & 24.59 & 98.56 \\
\hline BD9 & 31.3 & 10.8 & 10.1 & 15.2 & 4.0 & 0.175 & 0.46 & 0.17 & 0.53 & 2.18 & 24.91 & 99.82 \\
\hline BD10 & 24.4 & 8.2 & 13.1 & 17.6 & 2.8 & 0.222 & 0.37 & 0.16 & 0.38 & 1.69 & 30.06 & 98.98 \\
\hline BD11 & 22.6 & 7.5 & 13.9 & 18.4 & 2.9 & 0.216 & 0.35 & 0.16 & 0.33 & 1.37 & 31.68 & 99.41 \\
\hline BD12 & 26.1 & 8.9 & 12.9 & 16.3 & 3.0 & 0.307 & 0.38 & 0.16 & 0.45 & 1.55 & 28.67 & 98.72 \\
\hline BD13 & 6.2 & 2.1 & 19.6 & 27.0 & 0.8 & 0.115 & 0.12 & 0.13 & 0.07 & 0.13 & 42.50 & 98.76 \\
\hline BD14 & 18.6 & 6.7 & 15.2 & 19.9 & 2.0 & 0.714 & 0.25 & 0.16 & 0.24 & 1.00 & 34.15 & 98.91 \\
\hline BD15 & 28.5 & 9.0 & 12.3 & 15.4 & 3.3 & 0.211 & 0.45 & 0.18 & 0.42 & 1.79 & 27.39 & 98.94 \\
\hline BD16 & 29.3 & 9.1 & 12.3 & 15.5 & 3.3 & 0.398 & 0.44 & 0.19 & 0.42 & 1.70 & 27.75 & 100.40 \\
\hline BD 17 & 24.7 & 8.2 & 13.1 & 17.4 & 3.2 & 0.210 & 0.37 & 0.18 & 0.31 & 1.38 & 30.14 & 99.19 \\
\hline BD18 & 22.3 & 7.7 & 14.4 & 17.8 & 3.4 & 0.221 & 0.46 & 0.16 & 0.29 & 1.08 & 31.67 & 99.48 \\
\hline BD19 & 26.6 & 8.6 & 13.1 & 17.1 & 3.0 & 0.249 & 0.39 & 0.20 & 0.34 & 1.53 & 29.34 & 100.45 \\
\hline $\mathrm{BD} 20$ & 32.4 & 11.2 & 10.4 & 12.7 & 4.5 & 0.457 & 0.49 & 0.19 & 0.66 & 2.12 & 23.33 & 98.45 \\
\hline BD21 & 39.0 & 12.9 & 8.5 & 9.8 & 4.9 & 0.207 & 0.59 & 0.19 & 0.82 & 2.54 & 19.15 & 98.60 \\
\hline BD22 & 28.1 & 9.4 & 12.1 & 15.4 & 3.4 & 0.295 & 0.41 & 0.17 & 0.59 & 1.68 & 27.50 & 99.04 \\
\hline BD23 & 18.2 & 6.1 & 15.5 & 20.6 & 3.0 & 0.075 & 0.29 & 0.16 & 0.35 & 0.85 & 34.39 & 99.51 \\
\hline BD24 & 12.7 & 3.4 & 17.7 & 23.8 & 1.2 & 0.127 & 0.17 & 0.13 & 0.17 & 0.39 & 39.74 & 99.53 \\
\hline BD25 & 8.6 & 1.2 & 17.6 & 27.8 & 0.5 & 0.033 & 0.08 & 0.12 & $<0.05$ & 0.05 & 43.75 & 99.78 \\
\hline BD26 & 31.0 & 9.1 & 12.2 & 14.0 & 3.6 & 0.195 & 0.42 & 0.16 & 0.62 & 1.82 & 25.36 & 98.47 \\
\hline BD27 & 31.0 & 8.8 & 12.9 & 14.4 & 3.8 & 0.298 & 0.42 & 0.17 & 0.53 & 1.62 & 25.56 & 99.50 \\
\hline
\end{tabular}

"L.O.I. = loss on ignition 
Table 4. Chemical composition of bulk samples of dolostones from Sites 650, 651, and 655: trace elements (in ppm).

\begin{tabular}{|c|c|c|c|c|c|c|c|c|}
\hline Sample & $\mathrm{Sr}$ & $\mathrm{Ba}$ & V & $\mathrm{Ni}$ & Co & $\mathrm{Cr}$ & $\mathrm{Zn}$ & $\mathrm{Cu}$ \\
\hline BD1 & 154.0 & 96.0 & 75.6 & 59.9 & 26.5 & 47.7 & 62.9 & 32.4 \\
\hline BD2 & 155.0 & 92.1 & 85.3 & 87.1 & 37.4 & 58.0 & 66.4 & 44.5 \\
\hline BD4 & 157.0 & 59.5 & 46.3 & 59.3 & 16.4 & 25.9 & 31.2 & 25.7 \\
\hline BD5 & 881.0 & 122.0 & 91.9 & 18.7 & 18.5 & 64.2 & 50.6 & 21.1 \\
\hline BD6 & 283.0 & 185.0 & 126.0 & 50.0 & 29.0 & 82.6 & 72.3 & 38.7 \\
\hline BD7 & 108.0 & 151.0 & 107.0 & 39.8 & 25.7 & 73.9 & 67.9 & 56.3 \\
\hline BD8 & 105.0 & 116.0 & 92.6 & 38.0 & 18.9 & 76.7 & 71.1 & 23.4 \\
\hline BD9 & 108.0 & 142.0 & 147.0 & 39.4 & 18.3 & 94.2 & 69.4 & 18.4 \\
\hline BD10 & 70.0 & 116.0 & 79.1 & 33.2 & 22.1 & 63.5 & 53.4 & 63.2 \\
\hline BD11 & 75.3 & 109.0 & 64.3 & 20.7 & 14.6 & 57.6 & 47.5 & 33.8 \\
\hline BD12 & 88.0 & 140.0 & 63.1 & 26.1 & 20.3 & 48.9 & 58.0 & 37.1 \\
\hline BD13 & 75.9 & 26.0 & 21.8 & 7.5 & 7.9 & 18.6 & 19.3 & 12.6 \\
\hline BD14 & 89.5 & 157.0 & 51.0 & 57.4 & 28.9 & 35.7 & 45.6 & 29.4 \\
\hline BD15 & 77.4 & 137.0 & 83.3 & 80.0 & 20.3 & 67.5 & 65.8 & 40.2 \\
\hline BD16 & 97.2 & 183.0 & 84.5 & 33.0 & 26.9 & 66.9 & 61.8 & 47.1 \\
\hline BD17 & 79.6 & 125.0 & 80.9 & 50.6 & 19.6 & 87.8 & 59.5 & 26.9 \\
\hline BD18 & 82.8 & 11.8 & 69.2 & 57.4 & $<5.0$ & 57.8 & 28.2 & 41.2 \\
\hline BD19 & 86.5 & 136.0 & 78.9 & 63.4 & 26.5 & 69.0 & 59.6 & 46.0 \\
\hline BD20 & 82.9 & 187.0 & 105.0 & 63.2 & 39.4 & 96.2 & 80.3 & 66.1 \\
\hline BD21 & 88.6 & 207.0 & 115.0 & 69.6 & 19.6 & 96.3 & 88.2 & 52.1 \\
\hline BD22 & 100.0 & 187.0 & 88.7 & 56.4 & 25.7 & 67.6 & 66.0 & 51.2 \\
\hline BD23 & 73.6 & 100.0 & 59.9 & 22.4 & 14.1 & 47.8 & 45.9 & 31.3 \\
\hline BD24 & 81.6 & 46.8 & 41.1 & 29.8 & 12.5 & 30.8 & 21.5 & 15.0 \\
\hline BD25 & 121.0 & 16.3 & 13.6 & 9.6 & 11.3 & 16.0 & 9.2 & 13.4 \\
\hline BD26 & 75.1 & 184.0 & 83.0 & 101.0 & 34.2 & 74.4 & 68.3 & 57.5 \\
\hline BD27 & 89.9 & 314.0 & 74.0 & 98.0 & 28.3 & 82.6 & 66.4 & 55.1 \\
\hline
\end{tabular}

Table 5. Stable isotope data (\%) for carbonates.

\begin{tabular}{lrr}
\hline Sample & $\delta^{18} \mathrm{O}_{\mathrm{PDB}}$ & $\delta^{13} \mathrm{C}_{\mathrm{PDB}}$ \\
\hline BD1 & 1.16 & 2.61 \\
BD2 & 0.66 & 2.78 \\
BD4 & 5.32 & 1.87 \\
BD5 & 1.49 & 0.61 \\
BD6 & -0.55 & -0.29 \\
BD7 & 0.43 & 0.55 \\
BD8 & 3.33 & 1.08 \\
BD9 & 1.42 & 0.75 \\
BD10 & -1.47 & 0.46 \\
BD11 & -0.32 & 1.44 \\
BD12 & 1.31 & 2.60 \\
BD13 & 2.29 & 3.17 \\
BD14 & 1.63 & 2.34 \\
BD15 & -0.49 & 0.94 \\
BD16 & -0.21 & 1.27 \\
BD17 & -0.30 & 1.34 \\
BD18 & -0.96 & 1.33 \\
BD19 & -0.83 & 1.31 \\
BD20 & -0.33 & 1.59 \\
BD21 & 0.14 & 2.01 \\
BD22 & 0.64 & 2.19 \\
BD23 & 1.24 & 2.58 \\
BD24 & 2.22 & 2.34 \\
BD25 & 0.78 & 1.98 \\
BD26 & 0.03 & 1.62 \\
BD27 & 0.14 & 1.59 \\
BD28 & 1.03 & 3.03 \\
BD29 & 1.98 & 3.09 \\
BD30 & 2.61 & 3.53 \\
BD32 & 3.53 & 3.81 \\
BD33 & 2.43 & 3.61 \\
BD35 & 2.78 & 3.31 \\
& &
\end{tabular}

Table 6. Stable isotope data $(\% 0)$ for pore waters.

\begin{tabular}{lcc}
\hline $\begin{array}{c}\text { Core, section, } \\
\text { interval (cm) }\end{array}$ & $\begin{array}{c}\text { Depth } \\
\text { (mbsf) }\end{array}$ & $\delta^{18} \mathrm{O}_{\text {SMOW }}$ \\
\hline TSSW $^{\mathrm{a}}$ & & 1.13
\end{tabular}

107-651A-

\begin{tabular}{|c|c|c|}
\hline $1 \mathrm{R}-3,110-120$ & 4 & $\begin{array}{l}1.04^{b} \\
1.70^{\mathrm{c}}\end{array}$ \\
\hline $3 R-1,54-57$ & 11 & $1.06^{\mathrm{c}}$ \\
\hline $7 R-2,140-150$ & 53 & $\begin{array}{l}1.46^{b} \\
1.54^{\mathrm{c}}\end{array}$ \\
\hline $18 \mathrm{R}-5,140-150$ & 162 & $-0.50^{c}$ \\
\hline $26 \mathrm{R}-1,140-150$ & 234 & $1.09^{\mathrm{c}}$ \\
\hline $34 \mathrm{R}-1,140-150$ & 311 & $\begin{array}{l}1.23^{b} \\
1.41^{\mathrm{c}}\end{array}$ \\
\hline $39 \mathrm{R}-3,140-150$ & 362 & $1.33^{\mathrm{c}}$ \\
\hline
\end{tabular}

${ }^{\mathrm{a}}$ TSSW $=$ Tyrrhenian Sea surface water collected January, 1986.

b Interstitial water stored in glass.

c Interstitial water stored in plastic.

The equation of the second regression line fitted to these points is:

$$
\mathrm{Y}=1.7529+0.645 X(\mathrm{R}=0.95) \text {. }
$$

The lower of the two overlapping fields comprises Site 651 sedimentary $\mathrm{Mg}$-rich dolomite, which is relatively more depleted in both ${ }^{18} \mathrm{O}$ and ${ }^{13} \mathrm{C} ; \delta^{18} \mathrm{O}$ ranges from $-1.47 \%$ to $2.29 \%$ and $\delta^{13} \mathrm{C}$ ranges from $0.46 \%$ to $3.17 \%$. The upper field contains Site 651 basaltic Ca-rich dolomite and Site $650 \mathrm{Ca}$-rich dolomite, with a $\delta^{18} \mathrm{O}$ range between $0.78 \% 0$ and $3.53 \% 0$ and a $\delta^{13} \mathrm{C}$ range between $1.98 \% 0$ and $3.81 \% 0$.

The covariant trends defined by the isotope cross-plot could be indicative of different dolomitizing conditions. Normal sea 


\section{Average Mole \% Mg in 651A Dolomites}

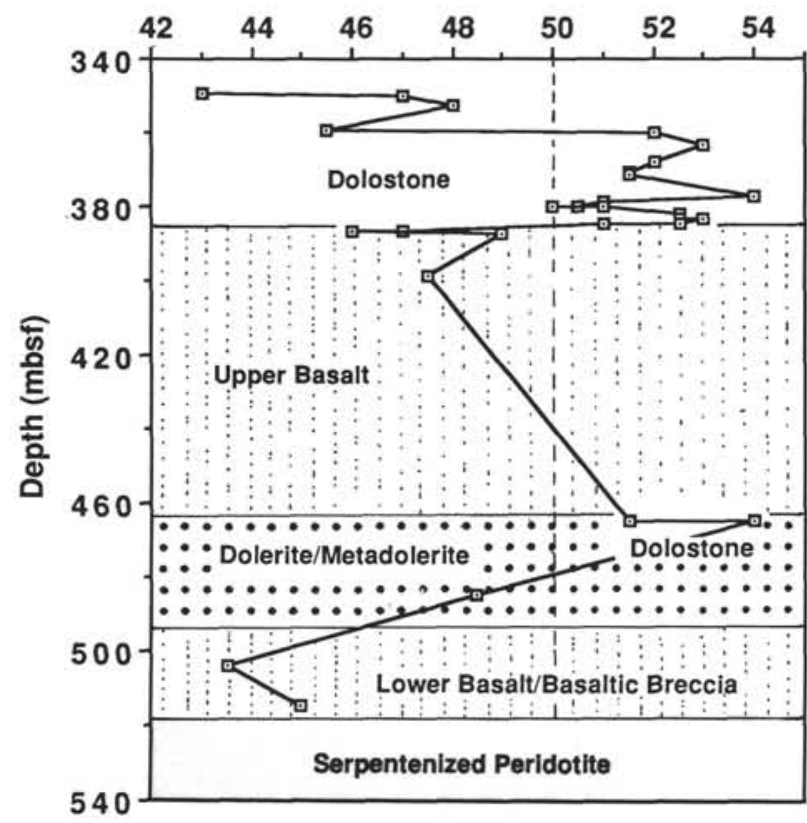

Figure 2. The average mol\% $\mathrm{Mg}$ in the Site 651 dolomites plotted against depth (mbsf). The dashed line at $50 \mathrm{~mol} \% \mathrm{Mg}$ represents stoichiometric dolomite. Note that the $\mathrm{Mg}$-rich dolomites occur in the sediments directly overlying the basement complex and in the sediments within the doleritic basement rocks, while the Ca-rich dolomites are found in the uppermost, presumably most recently dolomitized basal sediments and as cements and infillings in the basement rock.

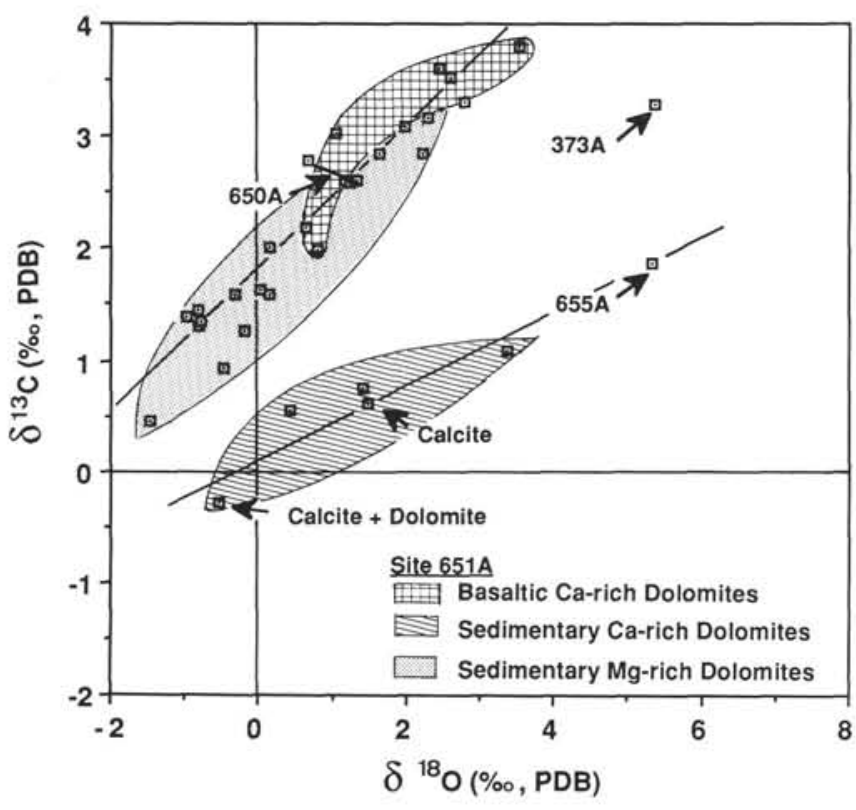

Figure 3. Cross-plot of the $\delta^{18} \mathrm{O}$ vs. $\delta^{13} \mathrm{C}$ values for carbonates recovered in basal sediments from the Tyrrhenian Sea, including values from DSDP Site 373 (Bernoulli et al., 1978). Two covariant trends, along the upper and lower linear regression fits, reflect variations in precipitation temperatures, dolomitizing solutions, and/or rates of precipitation. See text for discussion. water or solutions derived from sea water are potential dolomitizing solutions, from which Ca-rich dolomite is known to precipitate (e.g., Hardie, 1987). The precipitation of the unusual $\mathrm{Mg}$-rich dolomite probably requires a dolomitizing solution more concentrated in $\mathrm{Mg}$ ions and depleted in $\mathrm{Ca}$ ions than normal sea water. A singularly unique example of extensive $\mathrm{Mg}$-rich dolomite precipitation has been reported from modern coastal lakes in the Coorong region of South Australia (von der Borch, 1965; Boltz and von der Borch, 1984; Rosen et al., 1988). These $\mathrm{Mg}$-rich dolomites are found co-existing with magnesite and a genetic relationship is inferred, probably related to the cation concentrations (high $\mathrm{Mg} / \mathrm{Ca}$ ratios) of the alkaline lake waters. Gunatilaka et al. (1987) have reported a second occurrence of very small amounts of $\mathrm{Mg}$-rich dolomite in two cores from the Al-Kiran sabkha, Kuwait. Unlike the Coorong example, the precipitation of the Al-Kiran $\mathrm{Mg}$-rich dolomite is not presently associated with a calcium deficiency in the sabkha waters.

In sedimentary basins of the Inner Dinarides, Yugoslavia, Miocene deposits containing lacustrine magnesite and some $\mathrm{Ca}$ rich dolomite are found in association with ultramafic rocks (Ilich, 1974, and references therein). Upward-migrating hydrothermal solutions of volcanic origin, which reacted with the ultramafic rocks (including serpentinized peridotite) and Upper Triassic limestones through which they passed, were proposed as the source of the ions for these deposits. After the solutions surfaced and flowed into the bottom of the lakes, chemical disequilibrium conditions resulted in the precipitation of authigenic carbonates. Ilich (1974) has proposed that this hydrothermalsedimentary dolomite may be the missing link between dolomites formed under pure sedimentary conditions and those of pure hydrothermal origin. Recent studies in the Jarando Basin indicate that magnesite with rare dolomite was precipitated at approximately $25^{\circ} \mathrm{C}$ from shallow, alkaline lake waters which experienced temporary subaerial and evaporative conditions (Obradovic, 1983; Obradovic et al., 1984).

The Site $651 \mathrm{Mg}$-rich dolomite was not found in association with magnesite, although unusual environmental conditions were probably required for its precipitation, as suggested by the examples discussed above. One possible scenario is that $\mathrm{Mg}$-enriched solutions could have been derived from the reaction of circulating sea water with the underlying basement complex. In particular, low-temperature serpentinization of the peridotite body could have released excess $\mathrm{Mg}$ to form potentially dolomitizing fluids, which subsequently migrated into the overlying sediment package. Higher alteration temperatures must be excluded from the Site 651 scenario because the reaction of sea water with basement rocks between approximately 70 and $500^{\circ} \mathrm{C}$ is characterized by the extremely efficient removal of $\mathrm{Mg}$ into the alteration by-products (Mottl, 1983, and references therein). Thus, $\mathrm{Mg}$ would be released to hydrothermal solutions only during low-temperature reactions.

Recent studies (Bonatti et al., 1984; Kimball et al., 1985) suggest that low-temperature serpentinization does occur in the deep-sea environment. Assuming a fluid similar to modern sea water and using oxygen isotopic data, serpentinization temperatures of mantle-derived ultramafic bodies from the equatorial Atlantic were estimated to have been between $30^{\circ}$ and $180^{\circ} \mathrm{C}$ (Bonatti et al., 1984), while temperatures for the last serpentinization event in ultramafics from the Islas Orcadas fracture zone, South Atlantic, may have been as low as $25^{\circ} \mathrm{C}$ (Kimball et al., 1985).

In addition to a $\mathrm{Mg}$ source, a hydrologic mechanism would have been required to circulate or pump the dolomitizing solution through the sediment column in order to have produced the 40 - $\mathrm{m}$ thick dolostone sequence drilled at Site 651 . Normal hydrologic circulation via groundwater movement or compaction would probably not have been sufficient to transport enough 
$\mathrm{Mg}$ into the system to produce this massive dolomite deposit in a reasonable length of time. A hydrothermal gradient, which could use convection to drive low-temperature solutions through the underlying basement rocks and into the basal sediments, would eliminate the transport problem while allowing for the production of potentially dolomitizing fluids.

A second scenario for the dolomitization is that the Ca-rich dolomites are by-products of a low-temperature hydrothermal flux of sea water through the basement, while the unusual Mgrich dolomite may have been precipitated under entirely different environmental conditions during the Messinian salinity crisis. With the desiccation of the Mediterranean Sea, it is quite possible that lacustrine conditions, similar to those in Australia or Yugoslavia, could have existed during this time period at the present location of Site 651. As it is impossible to date the dolostones directly, it can only be assumed that they are older than the datable overlying pelagic sediments, which have a biostratigraphic age of Late Pliocene (MP16 biozone) (Shipboard Scientific Party, 1987b), and younger than the underlying basalt. At Site 652 , correlations of paleomagnetic reversals and biostratigraphic zones suggest that the MPl6 biozone is younger than 2.48 Ma (Shipboard Scientific Party, 1987c). Feraud (this volume) proposes tentative ${ }^{39} \mathrm{Ar} /{ }^{40} \mathrm{Ar}$ ages of 3.0 and $2.6 \mathrm{Ma}$ for the lower basalt and upper basalt units, respectively. These preliminary ages for the sediments and basalt, which sandwich the Site 651 dolostones, are in conflict with a Messinian origin for the $\mathrm{Mg}$-rich dolomite.

\section{Clay Mineralogy of Dolostones}

The X-ray diffraction investigation of the clay fraction indicates that the major component of the studied samples is smectite, ranging from approximately $60 \%$ to $80 \%$. Other clay components are minor kaolinite and illite and rare chlorite and mixed-layer minerals. The relatively high content of palygorskite in the clay fraction of samples from Site 651 (Samples BD5, BD9, BD12, BD16, BD23, BD26, and BD27) and Site 655 (Sample BD4) is rather unusual. The amount is variable from approximately $5 \%$ to $20 \%$ of the clay fraction but appears to increase downhole, with the greatest value found for Sample BD27. Samples BD20 and BD21 from Site 651 contained only rare palygorskite fibers, while Samples BD1 and BD2 from Site 650 contained none.

Observations of the clay fraction using TEM confirm the Xray diffraction analysis. The main components of the mineral assemblage are abundant, long fibers of palygorskite together with dominant, flaky particles of smectite [Pl. 1, Fig. 1]. At Site 651 , the palygorskite fibers become longer, denser, and more abundant closer to the basement, particularly in the sediments found beneath the upper basalt (Samples BD26 and BD27) [P1. 1, Fig. 4]. In all samples, the minor kaolinite appears as small, light, well-defined platelets [PI. 1, Fig. 3], and the illite or chlorite particles show typical "moiré" patterns. In some samples (e.g., Samples BD4, BD9, BD20, BD23, and BD26), iron oxyhydroxides occur as star-shaped or spindle aggregates [PI. 1, Fig. 2]. These morphologies are similar to those of lepidocrocite $(\gamma-\mathrm{FeOOH})$ or akaganéite $(\beta-\mathrm{FeOOH})$ or even goethite. The oxides are particularly abundant in Sample BD20 [Pl. 1, Fig. 3].

The prevalent smectites in the dolostones could have a detrital as well as authigenic origin. The TEM morphologies of the smectite particles are mostly similar to those of detrital origin. However, on some particles, lathy overgrowths suggest that the particles have been transformed or may be authigenic. The minor, but uniform content of illite and kaolinite and the scarce chlorite in the dolostones suggest that these clay minerals represent a detrital component. The irregular distribution of the small oxide minerals among the samples and sites, either absent or very abundant, and their morphologies, similar to oxyhy- droxides, suggest that they are authigenic. Likewise, the irregular distribution of the palygorskite, increasing in abundance downhole with the closer proximity to the serpentinized basement at Site 651 , as well as its common occurrence with oxyhydroxides, suggests an authigenic origin.

The authigenic occurrence of palygorskite, a fibrous Mg-clay mineral $\left[\left(\mathrm{OH}_{2}\right)_{4} \mathrm{Mg}_{5} \mathrm{Si}_{8} \mathrm{O}_{20}(\mathrm{OH})_{2} \cdot 4 \mathrm{H}_{2} \mathrm{O}\right]$, in deep-sea sediments is attributed to interactions between solution and sediments during diagenetic or hydrothermal processes. The formation and stability of palygorskite are promoted by high $\mathrm{Si}$ and $\mathrm{Mg}$ activities, low $\mathrm{Al}$ concentrations, alkaline $\mathrm{pH}$ and high temperatures. Based on thermodynamic calculations and field observations, palygorskite would be a stable mineral under marine conditions (Kastner, 1981, and references therein).

Abundant authigenic palygorskite has been recognized in sedimentary layers and concretions associated with volcanic and tectonic features (Hathaway and Sachs, 1965; Bonatti and Joensuu, 1968; Bowles et al., 1971; Church and Velde, 1979; and Bonte et al., 1980). In these occurrences, the genesis of the palygorskite is attributed to hydrothermal processes with direct crystallization from $\mathrm{Mg}$-rich solutions. These solutions are thought to be deep-circulating fluids, containing possibly some sea water, which may have reacted with the sediments or basement rock through which they circulated. This hydrothermal activity may be a relatively low-temperature phenomenon, as an isotopic temperature for deep-sea palygorskite formation in the Pacific was found to be approximately $50^{\circ} \mathrm{C}$ (Church and Velde, 1979).

The association of the Mg-rich clay (palygorskite) with the $\mathrm{Mg}$-rich dolomite suggests that the two minerals have precipitated from the same (or similar) Mg-rich solutions circulating through the basal sediments at Site 651. The absence of both minerals at Site 650 and the occurrence of palygorskite together with a Ca-rich dolomite in the basal sediments at Site 655 implies that the fluids altering the sediments may have had variable chemistries, which may be in turn related to the different chemistries of the directly underlying basement rocks. In any case, if the solutions were saturated in $\mathrm{Mg}$ and $\mathrm{Si}$ with respect to palygorskite, high temperatures would not be required for its formation (Kastner, 1981). Furthermore, an alkaline pH could be obtained during the dissolution-reprecipitation reactions of the carbonates, meeting further equilibrium conditions. The presence of authigenic palygorskite thus corroborates the proposition that low-temperature, $\mathrm{Mg}$-rich, hydrothermal solutions were convected through the near-surface basement rock and into the overlying basal sediments.

\section{Temperature of Dolomite Formation}

The oxygen isotope ratio of the diagenetic dolomite and the ratio of its formation water can be used to calculate the isotopic equilibrium temperature of precipitation using the following dolomite-water fractionation equation (Matthews and Katz, 1977):

$$
10^{3} \ln \alpha_{\text {dolomite-water }}=3.06 \times 10^{6} \mathrm{~T}^{-2}-3.24 .
$$

This equation was chosen for the temperature calculations because it was derived experimentally for non-stoichiometric dolomite produced by secondary replacement of calcium carbonate at temperatures between $252^{\circ}$ and $295^{\circ} \mathrm{C}$. These hydrothermal experiments, although not ideal, could simulate the type of dolomitization processes which produced the basal dolostones. To calculate the fractionation factor between dolomite and water, the $\delta^{18} \mathrm{O}$ values (PDB) of the dolomites were recalculated relative to SMOW (Clayton et al., 1988).

With the readily available isotope ratios for the solid phases, it was hoped that the interstitial pore waters from Site 651 would yield a reasonable facsimile of the oxygen isotope composition of the dolomitizing solutions in order to calculate for- 
mation temperatures. Towards this end, 7 pore water samples taken from throughout the entire sediment column were analyzed. The data are not sufficient to fully evaluate the variations recorded in the $\delta^{18} \mathrm{O}$ values, which were complicated further by the storage of the water in both plastic and glass vials (see Table 6 ). Therefore, an average value of $1.32 \%$ for the lowermost samples (311 and $362 \mathrm{mbsf}$, both near and within the dolomitized zone) was selected for the equilibrium temperature calculations. This value is enriched in ${ }^{18} \mathrm{O}$ relative to normal sea water, but Mediterranean sea water is generally enriched due to the negative hydrologic balance in the region. Tyrrhenian Sea surface water collected during ODP Leg 107 had a value of $1.13 \%$.

The Site 655 dolomite (Sample BD4) has the most positive $\delta^{18} \mathrm{O}$ value of $5.32 \%$, similar to that at Site 373 . The calculated formation temperature is $14.0^{\circ} \mathrm{C}$, very similar to the bottomwater temperatures of $13.2^{\circ} \mathrm{C}$ measured in situ at Site 655 . Heat-flow measurements at $70.2 \mathrm{mbsf}$ yielded temperatures of $18.10 \pm 0.02^{\circ} \mathrm{C}$ (Shipboard Scientific Party, 1987d). The dolostone comes from 79.9 mbsf, suggesting that its calculated formation temperature represents precipitation at or near bottomwater temperatures.

At the opposite extreme, the most negative $\delta^{18} \mathrm{O}$ value of $-1.47 \%$ for a Site 651 dolostone (Sample BD10, 360 mbsf) represents an isotope equilibrium temperature of $44.5^{\circ} \mathrm{C}$. Based on one temperature measurement at $29.4 \mathrm{mbsf}$, a geothermal gradient of $14.6 \pm 1{ }^{\circ} \mathrm{C} / 100 \mathrm{~m}$ was estimated for Site 651 (Shipboard Scientific Party, 1987b). Using this gradient and a bottom-water temperature of $13.4^{\circ} \mathrm{C}$, the sediments at $360 \mathrm{mbsf}$ would be at a temperature of $66.0 \pm 3.6^{\circ} \mathrm{C}$. Although higher than the calculated temperature, it is reasonably close, considering the error introduced by both the sparse thermal measurements and the equilibrium equation.

Calculated temperatures for the other dolomite samples with intermediate $\delta^{18} \mathrm{O}$ values would fall between $14.0^{\circ}$ and $44.5^{\circ} \mathrm{C}$, assuming that the isotopic composition of the dolomitizing solution was $1.32 \%$. If this assumption is only approximately correct, the calculated equilibrium temperatures still indicate that all of the dolomites were formed at or near ambient bottom-water conditions or from low-temperature $\left(<70^{\circ} \mathrm{C}\right)$ hydrothermal solutions. It is interesting to note that the range of $\delta^{18} \mathrm{O}$ values is nearly equivalent for both of the covariant trends.

\section{Isotopic Covariance}

For carbonates, a change in $\delta^{18} \mathrm{O}$ of $0.2 \%$ represents a temperature change of approximately $1^{\circ} \mathrm{C}$ (Epstein, et al., 1953). On the other hand, carbon isotopic fractionation in carbonates is not as sensitive to temperature changes. The rate of change for calcite is approximately $0.035 \%$ for a temperature change of $1^{\circ} \mathrm{C}$ (Emrich et al., 1970). In Figure 3, there appears to be at least two covariant trends emerging from the isotope cross-plot. The regression lines fitted to these two trends yield slopes on the order of 2 to 4 times steeper than would be predicted if the only variable in the system were temperature. Apparently, temperature is not the only controlling factor in the diagenesis.

Indeed, the two straight-line trends could signify that there may have been at least two distinctly different dolomitizing solutions. The less colorful, Ca-rich dolomites from the upper level of the Site 651 basal dolostones fall on the line of the lower trend (Fig. 3), along with the undolomitized sediment and the shallowly buried, Site $655 \mathrm{Ca}$-rich dolomite. If the dolomitization of an original calcareous sediment proceeds in an upward direction away from the basement rocks at Site 651, the most recently formed dolomites would be those which are in contact with the undolomitized overlying sediment. We propose that the most recent, dolomitizing, fluid producing the basal dolostones is (or was) altered sea water similar to the present pore waters; this fluid was driven through the sediments by hydrothermal cir- culation. The $\mathrm{Mg}$ concentration or the $\mathrm{Mg}$ : $\mathrm{Ca}$ ratio of this dolomitizing solution was not great enough to result in the precipitation of $\mathrm{Mg}$-rich dolomite, but was sufficient to produce palygorskite and Ca-rich dolomite. We suggest that sea water is also the dolomitizing fluid at Site 655 because of the isotopic similarity between the Site $655 \mathrm{Ca}$-rich dolomite and the most recent Site $651 \mathrm{Ca}$-rich dolomite, the shallow burial depth (79.9 mbsf), and the presence of palygorskite.

The slope of the upper covariant trend is twice that of the lower trend, indicating that the rate of change in the carbon isotopes is more extreme for the same oxygen-isotope range (Fig. 3 ). The greater enrichment in the ${ }^{13} \mathrm{C}$ content of the Site 651 basaltic Ca-rich dolomite over the Site 651 sedimentary $\mathrm{Mg}$-rich dolomite could signify that there were different carbon sources with different isotopic compositions. On the other hand, if the $\delta^{13} \mathrm{C}$ value of the dissolved inorganic carbon in the system were constant, the increased slope could suggest that the carbon-isotope fractionation factor for the sedimentary $\mathrm{Mg}$-rich dolomite is smaller than for the basaltic Ca-rich dolomite. Turner (1982) found that fractionation during calcite precipitation was dependent on reaction kinetics and noted that the enrichment of ${ }^{13} \mathrm{C}$ in the calcite was much greater when the precipitation rate was very slow, but was small and constant at faster rates.

Similarly, Rosen et al. (1988) concluded that the unusual crystal chemistry and heterogeneous microstructure of the $\mathrm{Mg}$ rich dolomite from the Coorong was a consequence of rapid precipitation. Together, the conclusions of both Turner (1982) and Rosen et al. (1988) suggest that relatively more rapid precipitation could likewise be the cause of the smaller ${ }^{13} \mathrm{C}$ enrichment in the Site 651 sedimentary $\mathrm{Mg}$-rich dolomite, in contrast to the larger enrichment in the Site 651 basaltic $\mathrm{Ca}$-rich dolomite. The different ranges of oxygen-isotope values for the two types of dolomite (Fig. 3) tend to confirm this interpretation. The generally more negative $\delta^{18} \mathrm{O}$ values of the sedimentary $\mathrm{Mg}$-rich dolomite could reflect precipitation at higher equilibrium temperatures, while the more positive $\delta^{18} \mathrm{O}$ values of the basaltic $\mathrm{Ca}$-rich dolomite could indicate relatively cooler equilibrium temperatures, suggesting a slower rate of precipitation.

The systematic heterogeneity in the stable isotopic data suggests that the dolomitizing rates and the formation temperatures of the basal dolostones are multiple. Aside from the general covariant trends, there appears to be no stratigraphic control on the isotope temperature, as demonstrated in a plot of oxygen isotope variations vs. depth at Site 651 (Fig. 4). For example, there is no suggestion of progressively cooler temperatures (i.e., more positive $\delta^{18} \mathrm{O}$ values) moving upward from the sediment/ basalt contact. If the oxygen isotope ratio is indeed an indirect measure of temperature, the fluctuations with depth seen in Figure 4 would indicate that warmer dolomitizing solutions moved through the sediment package in pulses. This hydrothermal flow may also be impeded or directed by impermeable layers or barriers, which could have produced the oxygen isotope ("temperature") pattern seen in the chemostratigraphy. In general, the data suggest that there is both a horizontal and vertical component to the fluid movement. The dolomitization has not been a homogeneous or single event but has occurred in discrete steps and may still be an ongoing process, as evidenced by heat flow measurements in the region.

\section{Metalliferous Basal Dolostones}

As exhibited by their intense colors, the bulk chemical analysis (Table 3 ) of the basal dolostones confirmed that they are actually very rich in iron oxides, with an average bulk weight percent $\mathrm{Fe}_{2} \mathrm{O}_{3}$ of $3.3 \%$. The average weight percent $\mathrm{Fe}_{2} \mathrm{O}_{3}$ for the non-carbonaceous component is $8.1 \%(\sigma=1.7 \%)$. The manganese content is also relatively high in comparison with normal pelagic calcareous ooze, which have ratios of $\mathrm{Fe} / \mathrm{Mn} \sim 10$. Two 


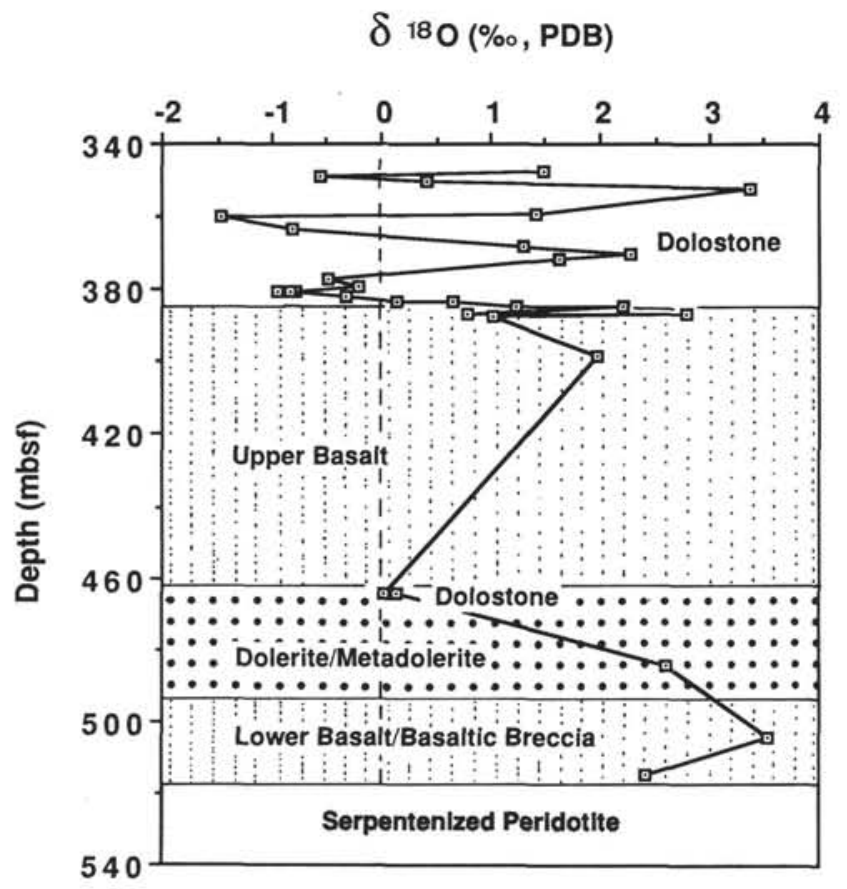

Figure 4. $\delta^{18} \mathrm{O}$ values of Site 651 dolomites plotted against depth (mbsf). Note that the values fluctuate widely between negative and positive values within the basal dolostone unit but maintain relatively more positive values within the basement complex, exclusive of the dolomitic sediments entrapped in the dolerite unit. Warmer isotopic equilibrium temperatures are to the left of the diagram, while cooler temperatures are to the right. The calculated isotopic temperatures for the Site 651 dolomites range between $21.3^{\circ}$ and $44.5^{\circ} \mathrm{C}$.

samples from Site 650 (BD1 and BD2) are very enriched in $\mathrm{Mn}_{3} \mathrm{O}_{4}$, having approximately 8 times more than the average bulk weight percent of $0.22 \%$, as measured in the other basal dolostones. Also, Sample BD14 from Site 651 is 3 times more enriched than the others, with which it is stratigraphically associated. Overall, the average weight percent $\mathrm{Mn}_{3} \mathrm{O}_{4}$ for the noncarbonaceous component is $0.95 \%(\sigma=1.0 \%)$. The ratio of $\mathrm{Fe} / \mathrm{Mn}$ in the dolostones is between 2.8 and 40 , with the large variation resulting mainly from varying $\mathrm{Mn}$ concentrations.

Plotting the Fe-Mn- $(\mathrm{Ni}+\mathrm{Co}+\mathrm{Cu}) \times 10$ compositions of the studied ODP Leg 107 basal sediments on a ternary diagram (following the method of Bonatti et al., 1972, and Toth, 1980) places them within the field of normal deep-sea sediments such as pelagic clays or calcareous oozes (Fig. 5). Some samples, however, fall closer to the region defined by the metalliferous sediments from the East Pacific Rise (EPR). In particular, the three samples (BD1, BD2 and BD14) that have the greatest manganese enrichment (and a very slight enrichment in trace transition elements) are strongly correlative to basal metalliferous deposits of hydrothermal origin. Three other samples (BDl2, BDl3 and BDI6) fall just barely within the field of the EPR metalliferous deposits. Generally, such basal deposits are related to hydrothermal metallogenesis at the spreading axis under oxidizing conditions and are found on ridge flanks and the sides of seamounts at the contact between the basement and pelagic cover (Bonatti, 1981). The pattern of Fe and Mn enrichment, with Fe/ $\mathrm{Mn}>1$, and the very low trace metal contents in the studied dolostones suggest that there has been remobilization of iron directly by hydrothermal fluids and/or by uptake from altered detrital components. With upward migration and diffusion, the metals reached cooler and more oxygenated sediments and precipitation occurred.

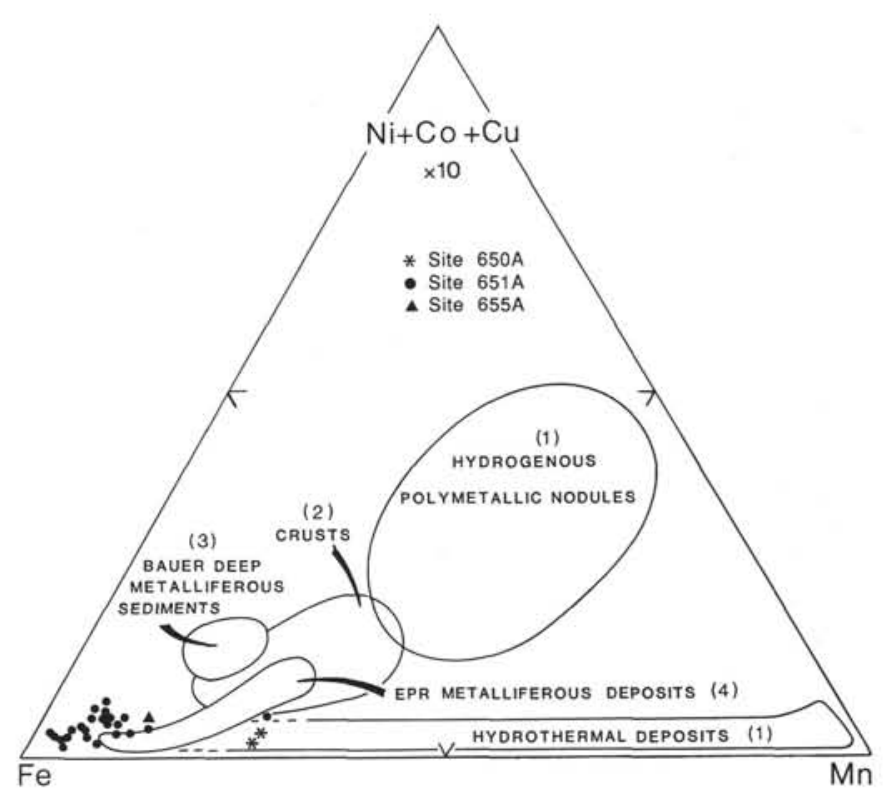

Figure 5. Ternary diagram for $\mathrm{Fe}-\mathrm{Mn}-(\mathrm{Ni}+\mathrm{Co}+\mathrm{Cu}) \times 10$ from Bonatti et al., (1972) and Toth (1980), showing the plotted position of dolostones from Sites 650,651 , and 655 in relationship to other oceanic facies. The areas defined by the other oceanic facies are: (1) hydrothermal deposits, characterized by very low trace-metal contents and located between the $\mathrm{Fe}$ and $\mathrm{Mn}$ apices, and "hydrogenous" polymetallic nodules (Bonatti et al., 1972; Bonatti 1981); (2) Fe-Mn crusts (Toth, 1980); (3) Bauer Deep metalliferous sediments (Sayles and Bischoff, 1973); and (4) East Pacific Rise (EPR) metalliferous deposits from various sites, representing from left (higher Fe values) to right (Mn enrichment) samples from the axial zone, the crest sides, and the deeper ridge flanks (basal metalliferous sediments), respectively (Germain-Fournier, 1986 and references therein).

The metalliferous dolostones from Site 650 (Samples BD1 and BD2) and Site 655 (Sample BD4) differ from the dolostones at Site 651 in that they represent only a very thin unit (approximately $2.1 \mathrm{~m}$ and $25 \mathrm{~cm}$, respectively). The extensive, $40-\mathrm{m}$ thick basal unit at Site 651 was visibly metalliferous, with abundant manganese oxide segregations present as burrow fills and in disseminated dendritic patterns. The input of $\mathrm{Mn}$ via hydrothermal circulation, as well as iron enrichment of the basal sediments, is a slow process. To accumulate significant $\mathrm{Mn}$ and $\mathrm{Fe}$ concentrations throughout a 40-m-thick unit would require time. The relatively slow movement (or diffusion) of ions, derived from the alteration of the underlying mafic rocks, could have produced the dendritic pattern seen within the semi-closed basal unit. It is undoubtedly significant that the most Mn-rich sample (BD14) lies stratigraphically less than $1 \mathrm{~m}$ beneath an extremely indurated dolostone (Sample BD13); the dolostone may act as an impedance layer that slows the upward migration of the hydrothermally driven fluids, thus allowing for a greater accumulation of $\mathrm{Mn}$ oxides.

\section{Basal Dolostones and Seismic Reflectors}

The entire dolomitic basal unit at Site 651 could impede significantly the flow of the hydrothermal fluids. Shipboard physical property measurements showed that between 324 and 330 mbsf there is a sharp increase in bulk density from 1.66 to 2.13 $\mathrm{g} / \mathrm{cm}^{3}$, accompanied by a significant decrease in porosity from $85 \%$ to $45 \%$ (Shipboard Scientific Party, 1987b). This dramatic change in the physical properties of the sediments probably marks the uppermost boundary of the diagenetic front and may even represent the top of a seismic reflector. From the interpre- 
tation of seismic reflection profiles on the basis of both differentiated seismic characteristics and slight unconformities (Shipboard Scientific Party, 1987b), a Seismic Subunit 3A can be distinguished between the base of Seismic Unit 2 at 330 to 350 mbsf and the top of Seismic Subunit 3B, the sediment/basalt contact. The base of Seismic Unit 2 lies slightly unconformably on Seismic Subunit $3 \mathrm{~A}$; the contact is characterized by rather continuous, slightly undulating reflectors.

Seismic Subunit $3 \mathrm{~A}$ correlates with the sedimentary sequence comprising the lowermost nannofossil chalk to brightly colored dolostone. Its distinction as a seismic unit is a by-product of the dolomitization and metalliferous input to the sediments via hydrothermal circulation. Thus, the reflector represents a diagenetic or alteration horizon that when traced for any lateral extent could be used to map out patterns of hydrothermal circulation within the basin. These diagenetic plumes may correlate with the dispersed seismic anomalies (the so-called "bright spots") recorded in seismic studies of the Tyrrhenian Sea (pers. comm., W.B.F. Ryan)

\section{CONCLUSIONS}

Dolomitization of basal sediments has been recorded at three ODP sites in the Tyrrhenian Sea. In particular, at Site 651 deep sea drilling recovered an approximately 40-m-thick dolostone unit that contained both $\mathrm{Ca}$-rich and $\mathrm{Mg}$-rich dolomite. In sedimentology, the formation of such massive dolostones remains problematic, as the precipitation of dolomite under earth surface conditions is hindered by both its highly ordered crystal structure and the difficulty of moving sufficient fluid through the sediments to accomplish the dolomitization. Apparently, the presence of a hydrothermal flux can overcome these kinetic and hydrologic barriers. The calculation of isotope equilibrium temperatures for the dolomites indicates that the reactions occurred at relatively low temperatures $\left(<70^{\circ} \mathrm{C}\right)$. The occurrence of both $\mathrm{Ca}$-rich and $\mathrm{Mg}$-rich dolomites suggests rapid precipitation, as the ionic ordering required to form an ideal stoichiometric dolomite is absent. The unusual presence of $\mathrm{Mg}$-rich dolomite in deep-sea sediments at Site 651 , in association with abundant palygorskite (a Mg-rich clay mineral), can be accounted for by a potential source of excess $\mathrm{Mg}$-ions derived from the low-temperature $\left(<70^{\circ} \mathrm{C}\right)$ alteration of the underlying serpentinized peridotite body in the basement complex.

The hydrothermally driven flux through the basal sediments has also resulted in the precipitation of substantial amounts of iron and manganese oxides. The manganese enrichments, along with a very slight enrichment in trace transition elements, strongly suggest that the basal sediments have an affinity to metalliferous deposits of hydrothermal origin. The low-temperature hydrothermal alteration and input of fresh material has drastically changed the physical properties of the basal sediments, decreasing the porosity and increasing the bulk density. As a result, massive basal dolostones, such as those at Site 651, are detectable in seismic reflection profiles, and their areal extent could be used to map the distribution of hydrothermal plumes within the back-arc basin of the Tyrrhenian Sea.

\section{ACKNOWLEDGMENTS}

We wish to acknowledge that this research was accomplished using facilities at the following institutions: Department of Geology, University of Florida; Stable Isotope Laboratory, RSMAS, University of Miami; and Centre de Sédimentologie and Géochimie de la Surface (CNRS), Strasbourg, France. This research was partially supported by USSAC Grant $\# 86032118$ to J. A. McKenzie and NSF Grant EAR-8417424 to P. K. Swart

\section{REFERENCES}

Bernoulli, D., Garrison, R. E., and McKenzie, J., 1978. Petrology, isotope geochemistry, and origin of dolomite and limestone associated with basaltic breccia, Hole 373A, Tyrrhenian Basin. In Hsü, K. J., Montadert, L., et al., Init. Repts. DSDP, 42: Washington (U.S. Govt. Printing Office), 541-558.

Besnus, Y., and Rouault, R., 1973. Une méthode d'analyses des roches au spectrométre d'arc a lecture directe par un dispositif d'électrode rotative. Analysis, 2:111-116.

Boltz, R. W., and von der Borch, C. C., 1984. Stable isotope study of carbonate sediments from the Coorong area, South Australia. Sedimentology, 31:837-849.

Bonatti, E., 1966. Deep-sea authigenic calcite and dolomite. Science, $153: 534-537$

1981. Metal deposits in the oceanic lithosphere. In Emiliani, C. (Ed.), The Sea (Vol. 7): New York (John Wiley \& Sons), 639-686.

Bonatti, E., and Joensuu, O., 1968. Palygorskite from Atlantic deepsea sediments. Am. Min., 53:975-983.

Bonatti, E., Kraemer, T., and Rydell, H. S., 1972. Classification and genesis of submarine iron-manganese deposits. In Horn, E. R. (Ed.), Ferromanganese Deposits on the Ocean Floor: Washington (National Science Foundation), 149-167.

Bonatti, E., Lawrence, J. R., and Morandi, N., 1984. Serpentinization of oceanic peridotites: temperature dependence of mineralogy and boron content. Earth Planet. Sci. Lett., 70:88-94.

Bonte, P., Lalou, C., and Latouche, C., 1980. Ferromanganese deposits in cores from Kane and Atlantis fracture area: possible relationship with hydrothermalism. J. Geol. Soc. Lond., 137:373-377.

Bowles, F. A., Angino, E. A., Hosterman, J. W., and Galle, O. K., 1971. Precipitation of deep-sea palygorskite and sepiolite. Earth Planet. Sci. Lett., 11:324-332.

Church, T. M., and Velde, B., 1979. Geochemistry and origin of a deepsea Pacific palygorskite deposit. Chem. Geol., 25:31-39.

Clayton, R. N., Jones, B. F., and Berner, R. A., 1968. Isotopic studies of dolomite formation under sedimentary conditions. Geochim. Cosmochim. Acta, 32:415-432.

Craig, H., 1957. Isotopic standards for carbon and oxygen and correction factors for mass-spectrometric analysis of carbon dioxide. Geochim. Cosmochim. Acta, 12:33-149.

Degens, E. T., and Epstein, S., 1964. Oxygen and carbon isotope ratios in coexisting calcites and dolomites from recent and ancient sediments. Geochim. Cosmochim. Acta, 28:23-44.

Emrich, K., Ehhalt, D. H., and Vogel, J. C., 1970. Carbon isotope fractionation during the precipitation of calcium carbonate. Earth Planet. Sci. Lett., 8:1307-1316.

Epstein, S., Buchsbaum, R., Lowenstam, H. A., and Urey, H. C., 1953. Revised carbonate water isotopic temperature scale. Geol. Soc. Am. Bull., 64:1315-1326.

Epstein, S., and Mayeda, T. 1953. Variations in ${ }^{18} \mathrm{O}$ content of waters from natural sources. Geochim. Cosmochim. Acta, 27:213-224.

Garrison, R. E., 1981. Diagenesis of oceanic carbonate sediments: A review of the DSDP perspective. In Warme, J. E., Douglas, R. G., and Winterer, E. L. (Eds.), The Deep Sea Drilling Project: A Decade of Progress: Soc. Econ. Paleontol. Mineral. Spec. Publ., 32:181-207.

Germain-Fournier, B., 1986. Les sédiments métallitéres océaniques actuels et anciens: caractérisation et comparaisons [Ph.D. dissert.]. Univ. Bretagne Occidentale, Brest, France.

Goldsmith, J. R., Graf, D. A., and Joensuu, O. I., 1955. The occurrence of magnesian calcites in nature. Geochim. Cosmochim. Acta, $7: 212-230$.

Gunatilaka, A., Saleh, A., Al-Temeemi, A., and Nassar, N., 1987. Calcium-poor dolomite from the sabkhas of Kuwait. Sedimentology, 34:999-1006.

Hardie, L.A., 1987. Dolomitization: a critical view of some current views. J. Sediment. Petrol., 57:166-183.

Jones, G. A., and Kaiteris, P., 1983. A vacuum-gasometric technique for rapid and precise analysis of calcium carbonate in sediments and soils. J. Sediment. Petrol., 53:655-660.

Hathaway, J. C., and Sachs, P.L., 1965. Sepiolite and clinoptilolite from the Mid-Atlantic ridge. Am. Min., 50:852-867.

Ilich, M., 1974. Hydrothermal-sedimentary dolomite: the missing link? AAPG Bull., 58:1331-1347.

Kastner, M., 1981. Authigenic silicates in deep-sea sediments: formation and diagenesis. In Emiliani, C. (Ed.), The Sea (Vol. 7): New York (J. Wiley \& Sons), 915-980.

Kimball, K. L., Spears, F. S., and Dick, H.J.B., 1985. High temperature alteration of abyssal ultramafics from the Islas Orcadas Fracture Zone, South Atlantic. Contrib. Mineral. Petrol., 91:307-320. 
Matthews, A., and Katz, A., 1977. Oxygen isotope fractionation during the dolomitization of calcium carbonate. Geochim. Cosmochim. Acta, 41:1431-1438.

McCrea, J. M., 1950. The isotopic chemistry of carbonates and a paleotemperature scale. J. Chem. Phys., 18: 849-857.

Mottl, M. J., 1983. Metabasalts, axial hot springs, and the structure of hydrothermal systems at mid-ocean ridges. Geol. Soc. Am. Bull., $94: 161-180$

Murata, K. J., and Erd, R. C., 1964. Composition of sediments from the experimental Mohole Project (Guadalupe Site). J. Sediment. Petrol., 34:633-655.

Obradovic, J., 1983. Some aspects of sedimentation in Neogene lake basins in Serbia. Abstr. 4th IAS Reg. Mtg., 4:120-121 (Abstract).

Obradovic, J., Karamata, S., and Vasic, N., 1984. Sedimentary magnesite from "Bela Stena" deposit and its origin. Abstr. 5th IAS Reg. Mtg., 5:330-331 (Abstract).

Rehault, J. P., Mascle, J., Fabbri, A., Moussat, E. and Thommeret, M., 1987. The Tyrrhenian Sea before Leg 107. In Kastens, K. A., Mascle, J., et al., Proc. ODP, Init. Repts., 107: College Station, TX (Ocean Drilling Program), 9-35.

Riedel, W. R., Ladd, A. S., Tracey, J. I., Jr., and Bramlette, M. N., 1961. Preliminary drilling phase of the Mohole Project II. Summary of coring operations. AAPG Bull., 45:1793-1798.

Rosen, M. R., Miser, D. E., and Warren, J. K., 1988. Sedimentology, mineralogy and isotopic analysis of Pellet Lake, Coorong Region, South Australia. Sedimentology, 35:105-122.

Samuel, J., Rouault, R., and Besnus, Y., 1985. Analyse multiélémentaire standardisée des matériaux géologiques en spectrométrie d'emission par plasma a couplage inductif. Analysis, 13:312-317.

Sayles, F. L., and Bischoff, J. L., 1973. Ferromanganoan sediments in the equatorial East Pacific. Earth Planet. Sci. Lett., 19:330-336.
Sharma, T., and Clayton, R. N., 1965. Measurements of ${ }^{18} \mathrm{O} /{ }^{16} \mathrm{O}$ ratios of total oxygen of carbonates. Geochim. Cosmochim. Acta, 29: $1347-1353$.

Shipboard Scientific Party, 1987a. Site 650: Marsili Basin. In Kastens, K. A., Mascle, J., et al., Proc ODP, Init. Repts., 107: College Station, TX (Ocean Drilling Program), 129-285.

1987b. Site 651: Tyrrhenian Sea. In Kastens, K. A., Mascle, J., et al., Proc. ODP, Init. Repts., 107: College Station, TX (Ocean Drilling Program), 287-410.

1987c. Site 652: Lower Sardinian Margin. In Kastens, K. A., Mascle, J., et al., Proc. ODP, Init. Repts., 107: College Station, TX (Ocean Drilling Program), 403-597.

1987d. Site 655: Gortani Ridge, Western Vavilov Basin. In Kastens, K. A., Mascle, J., et al., Proc. ODP, Init. Repts., 107: College Station, TX (Ocean Drilling Program), 877-949.

Toth, J. R., 1980. Deposition of submarine crusts rich in manganese and iron. Geol. Soc. Am. Bull, 91:44-54.

Turner, J. V., 1982. Kinetic fractionation of carbon-13 during calcium carbonate precipitation. Geochim. Cosmochim. Acta, 46:1183-1191.

UNESCO, 1981. International Bathymetry Chart of the Mediterranean Intergovernmental Commission. Paris (UNESCO).

von der Borch, C. C., 1965. The distribution and preliminary geochemistry of modern carbonate sediments of the Coorong area, South Australia. Geochim. Cosmochim. Acta, 29:781-799.

Wachter, E. A., and Hayes, J. M., 1985. Exchange of oxygen isotopes in carbon dioxide-phosphoric acid systems. Chem. Geol., 52:365-374.

Date of initial receipt: 18 January 1988

Date of acceptance: 13 January 1989

MS 107B-124 

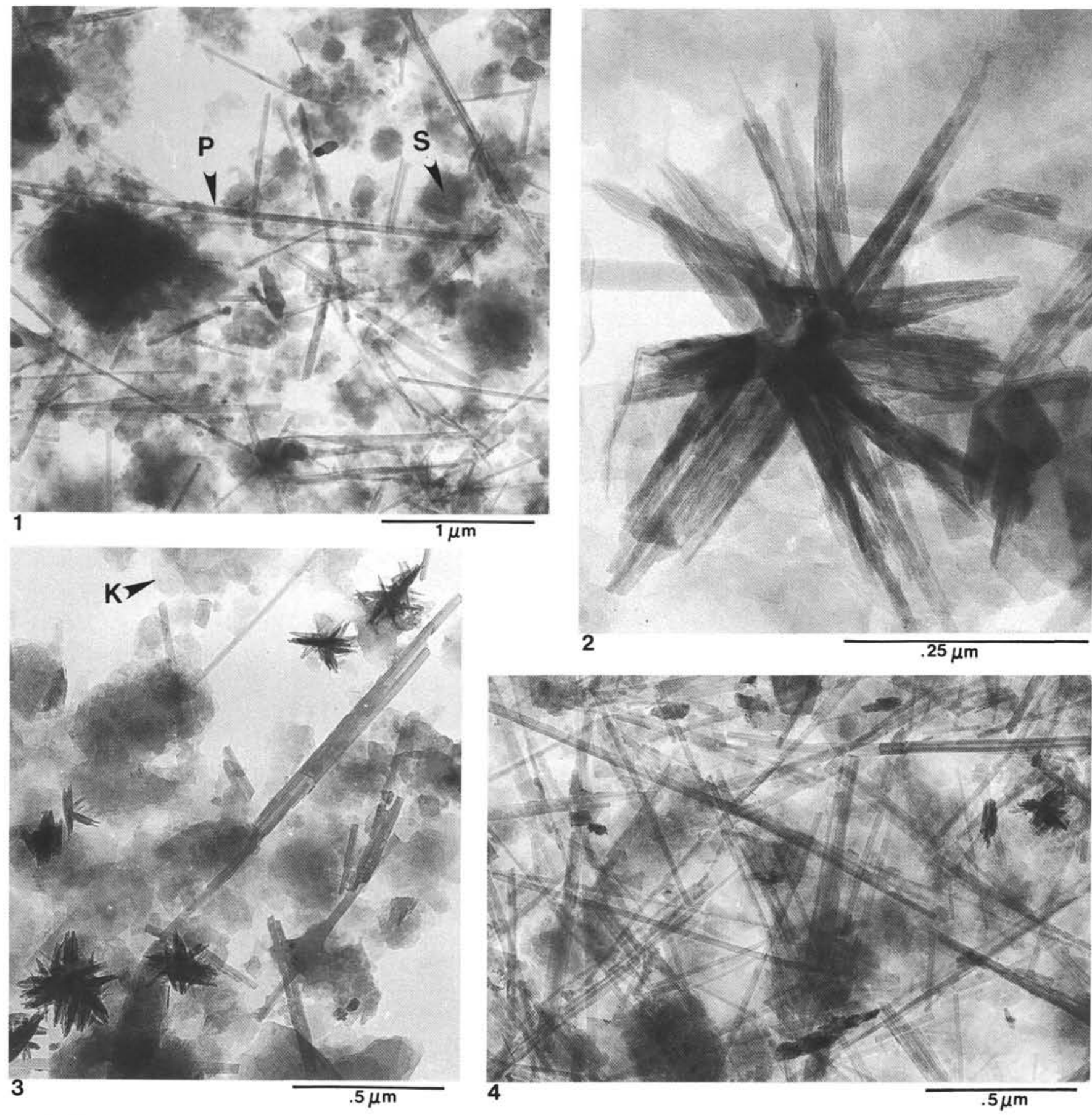

Plate 1. TEM photomicrographs of the untreated clay fraction $(<2 \mu \mathrm{m})$. 1. Sample 107-651A-39R-2, $20-21 \mathrm{~cm}$ (= Sample BD9): long, thin fibers of palygorskite $(\mathrm{P})$ associated with flaky particles of smectite $(\mathrm{S})$; scale bar $=1 \mu \mathrm{m}$. 2. Sample 107-651A-39R-2, 20-21 cm (= Sample BD9): small star-shaped particles of iron oxyhydroxides, such as lepidocrocite or akaganeite; scale bar $=0.25 \mu \mathrm{m}$. 3. Sample 107-651A-50R-1, 61-64 cm (= Sample BD27): abundant, very long, thin fibers of palygorskite, flaky smectite and scarce light particle of kaolinite $(\mathrm{K})$; scale bar $=0.5 \mu \mathrm{m}$. 4 . Sample 107-651A-50R-1, 61-64 cm (= Sample BD27): abundant, very long, thin fibers of palygorskite and scarce aggregates of star-shaped particles of iron oxyhydroxides; scale bar $=0.5 \mu \mathrm{m}$. 